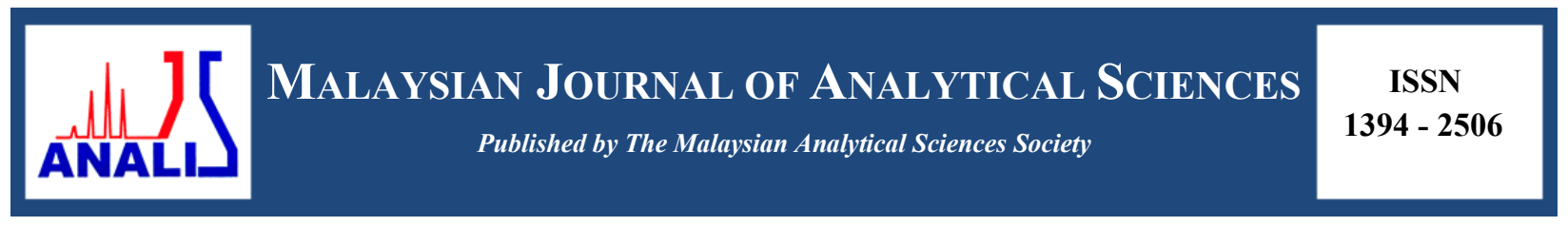

\title{
STUDIES OF INTERACTION BETWEEN TETRABUTYLAMMONIUM BROMIDE BASED DEEP EUTECTIC SOLVENT AND DNA USING FLUORESCENCE QUENCHING METHOD AND CIRCULAR DICHROISM SPECTROSCOPY
}

\section{(Kajian Interaksi antara Pelarut Eutektik Mendalam Berasaskan Tetrabutilamonium Bromida dan DNA Menggunakan Kaedah Pelindapkejutan Pendarfluor dan Spektroskopi Edaran Dikroisme)}

\author{
Rizana Yusof $^{1}$, Haslina Ahmad ${ }^{1,2}$, Mohd Basyaruddin Abdul Rahman ${ }^{1,2} *$ \\ ${ }^{l}$ Department of Chemistry, Faculty of Science \\ ${ }^{2}$ Enzyme and Microbial Technology Research Centre (EMTech) \\ Universiti Putra Malaysia, 43400 UPM Serdang, Selangor, Malaysia \\ *Corresponding author: basya@upm.edu.my
}

Received: 17 August 2015; Accepted: 17 August 2016

\begin{abstract}
The interaction of tetrabutylammonium bromide (TBABr)-based deep eutectic solvents (DESs) with calf thymus DNA (ct-DNA) was investigated by fluorescence and circular dichroism (CD) spectroscopy. The influences of hydrogen bond donors (HBDs), with respect to chain lengths and the presence of $\mathrm{OH}$ group were determined through ethidium bromide (EB) fluorescence quenching. Based on the quenching process, it was concluded that hydrophobic interactions were responsible for the DES ability to quench EB from EB-bound DNA. The strong electrostatic attraction between TBA ${ }^{+}$cation on DES and negative charge phosphate DNA was proved from fluorescence and CD spectroscopy. DNA was able to maintain its double helical structure at 25 ${ }^{\circ} \mathrm{C}$ with a concentration of $25 \%$ DES.
\end{abstract}

Keywords: binding, deep eutectic solvent, tetrabutylammonium bromide, fluorescence quenching, circular dichroism spectroscopy

\section{Abstrak}

Ikatan antara pelarut eutektik mendalam berasaskan tetrabutilammonium bromida (TBABr) dengan 'calf thymus' DNA (ctDNA) telah diuji dengan spektroskopi pendarfluor dan edaran dikroisme (CD). Pengaruh penderma ikatan hidrogen (HBDs) berdasarkan panjang rantai dan kehadiran kumpulan $\mathrm{OH}$ telah ditentukan melalui pelindapkejutan pendarfluor etidium bromida (EB). Berdasarkan proses pelindapkejutan, dapat dirumuskan bahawa ikatan hidrofobik berperanan dalam menentukan keupayaan DES untuk menyingkirkan EB daripada EB-terikat DNA. Tarikan elektrostatik yang kuat antara kation TBA $^{+}$pada DES dengan cas negatif fosfat DNA telah dibuktikan daripada kedua-dua spektroskopi pendarfluor dan CD. DNA berupaya mengekalkan struktur heliks berganda pada suhu $25^{\circ} \mathrm{C}$ dan kepekatan DES pada $25 \%$.

Katakunci: ikatan, pelarut eutektik mendalam, tetrabutilammonium bromida, pelindapkejutan pendarfluor, spektroskopi edaran dikroisme 


\section{Rizana et al: STUDIES OF INTERACTION BETWEEN TETRABUTYLAMMONIUM BROMIDE BASED DEEP EUTECTIC SOLVENT AND DNA USING FLUORESCENCE QUENCHING METHOD AND CIRCULAR DICHROISM SPECTROSCOPY}

\section{Introduction}

DNA is a biomacromolecule that plays an important role in the living organism because it stores the genetic information for cell replication and transcription. The potentials of DNA were increasingly recognized especially in the applications of biosensors, catalytic membranes, absorbing membranes and support for catalysts $[1,2]$. However, DNA is unstable in aqueous solution, resulting in denaturation of nucleic acid structure after 1 month of storage at ambient temperature [3]. Over the past few years, new solvents that can retain the DNA helical structure has been researched. Mamajanov et al. were among the first to propose deep eutectic solvent (DES) as an alternative solvent to maintain DNA helical structure and it was found that choline chloride: urea can maintain the DNA native structure [4]. However, the stability of DNA in the DES depends on the ability of DNA to maintain its helical structure, that could change during the interaction of DNA with other molecules. Recently, Sharma et al. found that hydrogen bonding and electrostatic interactions between bio-ionic liquids and DNA were found to be responsible for the long-term stability of DNA [5]. This finding enhanced the importance of studying the mode of interaction between DNA-DES to provide a stable medium for DNA.

Herein, the study of binding between tetrabutylammonium bromide (TBABr)-based DES and DNA by fluorescence quenching and CD spectroscopy was reported. The capability of DESs to quench EB from EB-bound DNA was explored using different HBDs with varying chain lengths and the number of $\mathrm{OH}$ group. In previous literature, it was reported that increasing the alkyl chain length of the cation in ionic liquid (IL) aided the quenching process [6]. In this study, the effect of HBDs chain length in DES on the quenching process was studied. The mode of interactions as well as stability of DESs in DNA were investigated.

\section{Materials}

\section{Materials and Methods}

Tetrabutylammonium bromide (TBABr), 1,3-propanediol and 1,5-pentanediol were supplied by Fluka Chemical (Reidstr, Steinheim, Germany) with $98 \%$ purity. Ethylene glycol was purchased from R\&M (Essex, UK) and glycerol was from J.T. Baker (Phillipsburg, NJ, USA). All chemicals were used without further purification. Deoxyribonucleic acid extracted from calf-thymus in the sodium salt form was purchased from CalBioChem. Ethidium bromide (EB) was purchased from Sigma-Aldrich (USA). Deionized water type III was used throughout the experiments.

\section{Synthesis of deep eutectic solvent (DES)}

$\mathrm{TBABr}$ salt was mixed with four different hydrogen bond donors (HBDs); ethylene glycol, 1,3-propanediol, 1,5-pentanediol and glycerol. The formation of DES mixture between TBABr and HBDs were done at molar ratio of 1:3. The mixtures were heated at $60{ }^{\circ} \mathrm{C}$ and stirred at $250 \mathrm{rpm}$ until colourless solution was observed. The mixtures were cooled to room temperature and sealed tightly in vials. DES mixtures were prepared accordingly to the method reported by Yusof et al. [7].

\section{Preparation of reagent solution}

Ethidium bromide $(\mathrm{EB})$ stock solution $\left(1.27 \times 10^{-3} \mathrm{~mol} \mathrm{~L}^{-1}\right)$ was prepared by dissolving $0.01 \mathrm{~g}$ of EB in $20 \mathrm{~mL}$ volumetric flask and stored in a cool and dark place. The dilution of EB stock solution was done for fresh preparation of $0.5 \mu \mathrm{M}$ EB.

\section{Preparation of DNA stock solution}

A stock solution of DNA was prepared by dissolving an appropriate amount (about $250 \mathrm{mg}$ ) of the solid DNA in deionized water type III and stored at $4{ }^{\circ} \mathrm{C}$ for about 24 hours. The solution was stirred until homogeneous DNA solution was produced. The solution was sonicated at a $40 \%$ amplitude, with setting of $30 \mathrm{~s}$ on and $50 \mathrm{~s}$ off for 20 minutes by the Digital Sonifier (Branson).

The final concentration and purity of the DNA stock solution was measured using UV-vis spectrophotometer (AV650). Diluted DNA stock solution $(3 \mathrm{~mL})$ in $1 \mathrm{~cm}$ pathlength cuvette was placed in the instrument. The absorbance at $260 \mathrm{~nm}$ was measured and corrected with the corresponding deionized water as a blank. The absorbance of the DNA was measured three times to obtain the average absorbance. The sample was scanned from $1000 \mathrm{~nm}$ to 290 $\mathrm{nm}$. The concentration of DNA stock solution was calculated from Beer's Law equation 1: 


$$
A=\varepsilon c l
$$

where $A$ is the absorbance value, $\varepsilon$ is an extinction coefficient constant $\left(6600 \mathrm{M}^{-1} \cdot \mathrm{cm}^{-1}\right.$ at $260 \mathrm{~nm}$ expressed in terms of base molarity), $c$ is the concentration of solution (M) and $l$ is a light path length (cm).

The purity of DNA solution was determined by measuring the ratio of the absorbance of the DNA stock solution (at $260 \mathrm{~nm}$ ) to that of the absorbance of protein (at $280 \mathrm{~nm}$ )[6]. The DNA solution was considered pure if the ratio of $\mathrm{A}_{260} / \mathrm{A}_{280}$ was above 1.8 .

\section{Fluorescence measurements}

Fluorescence emission of the solution was measured by using Cary Eclipse fluorescence spectrophotometer. In this study, EB was used as an intercalator. About $3 \mathrm{~mL}$ of $0.5 \mu \mathrm{M}$ EB was placed into $1 \mathrm{~cm}$ cuvette. The fluorescence spectra of the mixtures were recorded in the wavelength range of 550 to $750 \mathrm{~nm}$ with excitation wavelength at 510 $\mathrm{nm}$. Both the excitation and emission slits were set at a diameter of $5 \mathrm{~nm}$. A solution of DNA $(0.83 \mu \mathrm{M})$ was titrated into the cuvette, and allowed to reach equilibrium for 3 minutes. The emission spectrum was recorded. The DNA was titrated continuously into EB by increasing the DNA concentration from $0.83 \mu \mathrm{M}$ to $12.5 \mu \mathrm{M}$, while the concentration of $\mathrm{EB}$ was at $0.5 \mu \mathrm{M}$.

The prepared solution of DNA-bound EB was titrated with DES. The titration was done by increasing the concentration of the DES: $0.025,0.075,0.175,0.30,0.45,0.63,0.83,1.08,1.38$ and $1.73 \mathrm{M}$ into the same cuvette, while maintaining the concentration of DNA-bound EB. The solution was incubated for 3 minutes before the emission spectra were measured. The fluorescence emission spectra were recorded after each addition of the DES solution into the EB-bound DNA. This procedure was repeated for all the newly synthesized DES; TBABr:EG, TBABr:1,3-PD, TBABr:1,5-PD and TBABr:Gly.

\section{Circular dichroism measurements}

Circular dichroism spectroscopic measurements were performed by JASCO J-810 spectrophotometer equipped with a Peltier temperature controller (PTC-423s) and a water circulation unit. A fixed amount of DNA $(300 \mu \mathrm{M})$ was solubilized in $25 \%$ hydrated DESs at room temperature, $25{ }^{\circ} \mathrm{C}$. A quartz cuvette with a pathlength of $1.0 \mathrm{~cm}$ was used with a bandwidth at $1.0 \mathrm{~nm}$ and set at standard sensitivity. The measurements were taken at 320 to $200 \mathrm{~nm}$ wavelengths. Three scans were collected for each sample with a scan speed of $50 \mathrm{~nm} / \mathrm{min}$ and the average value taken. A spectrum of blank solution was recorded and subtracted from the spectra of DES and DNA complexes.

\section{The synthesis of DES}

\section{Results and Discussion}

$\mathrm{TBABr}$ salt was mixed with different HBDs; ethylene glycol (EG), 1,3-propanediol (1,3-PD), 1,5-pentanediol (1,5-PD) and glycerol (Gly) at $60^{\circ} \mathrm{C}$ with a molar ratio of 1:3. A clear homogenous liquid was observed after 2 to 3 hours of heating. Figure 1 shows the structures of the newly synthesized TBABr-based DES.

\section{The concentration and purity of DNA stock solution}

Figure 2 shows a broad absorption spectrum of DNA at 210 to $310 \mathrm{~nm}$ in the UV region with a maximum absorption at $260 \mathrm{~nm}$. The final concentration of DNA stock solution was estimated to be $0.0133 \mathrm{M}$ with the calculated $\mathrm{A}_{260} / \mathrm{A}_{280}$ as 1.8. This high ratio ensures a purity of DNA used for the experiments, as it was sufficiently free from protein contamination. The maximum absorption at $260 \mathrm{~nm}$ is an indicator of the chromophoric groups present in purine (adenine and guanine) and pyrimidine (cytosine and thymine) moieties that is responsible for the electronic transitions [8]. 


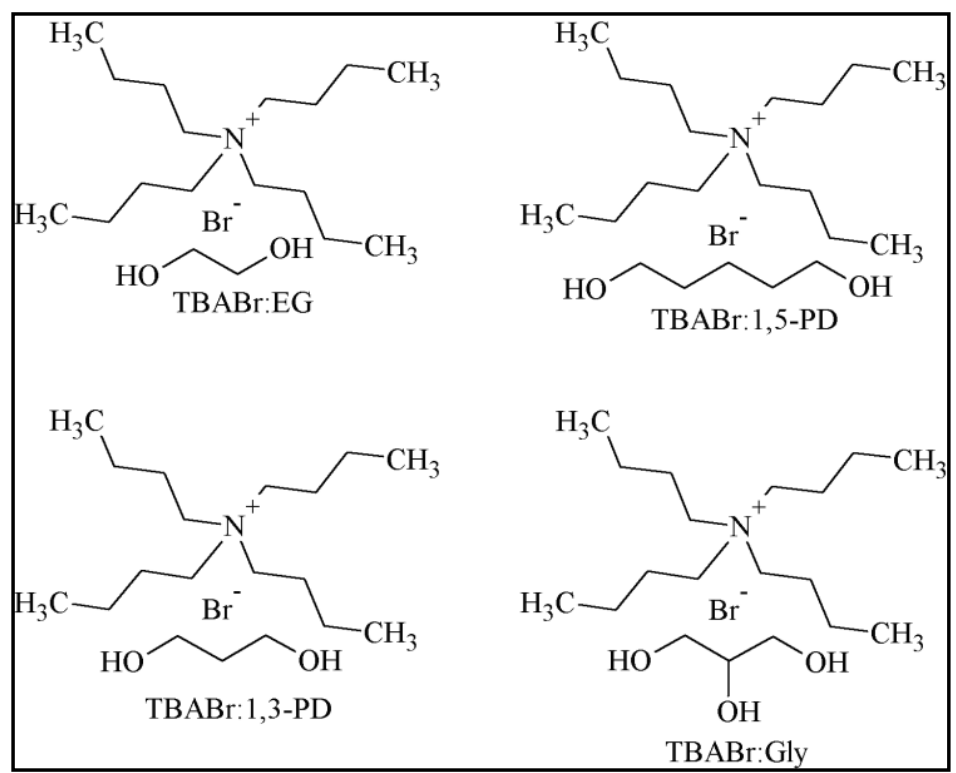

Figure 1. The newly synthesized TBABr-based DES

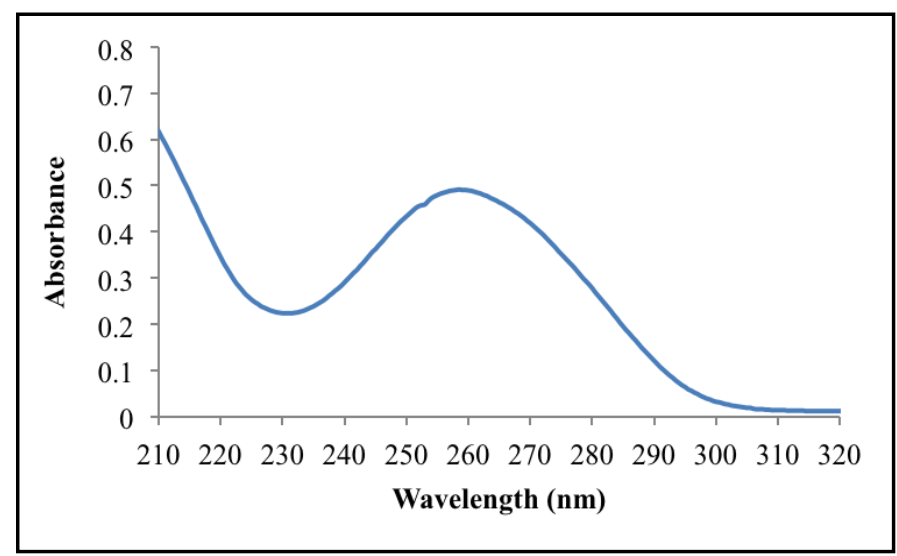

Figure 2. Absorbance spectrum of DNA in the UV region with a maximum absorption at $260 \mathrm{~nm}$

\section{Fluorescence quenching measurements}

Fluorescence spectroscopy is one of the most common methods used to study DNA binding. The high sensitivity of fluorescence able to detect the polarity changes causes spectral shifts in both the excitation and emission spectra of molecules [8]. In this work, a known intercalator, ethidium bromide (EB) was used as a fluorescence probe to intercalate the double helix of DNA. EB can be easily intercalated into the adjacent base pairs and stretch the double helix structures of DNA as it is made up of polycyclic, aromatic and planar structure $[6,8,9]$. Through intercalation, the DNA has to unwind in order to let the intercalator fit between the two base pairs. This process causes the DNA helix lengthening by $3.4 \AA$ as the bases are pushed apart hence resulting in conformational changes of the sugar group [10]. 
Figure 3 shows the emission intensity of free EB at $610 \mathrm{~nm}$ when excited at $510 \mathrm{~nm}$. The addition of DNA into free EB has increased the emission intensity with the peak shifted to a shorter wavelength $(595 \mathrm{~nm})$. The planar hydrophobic EB was shielded from the aqueous bulk solvent upon intercalation, which resulted in the increase of emission intensity.

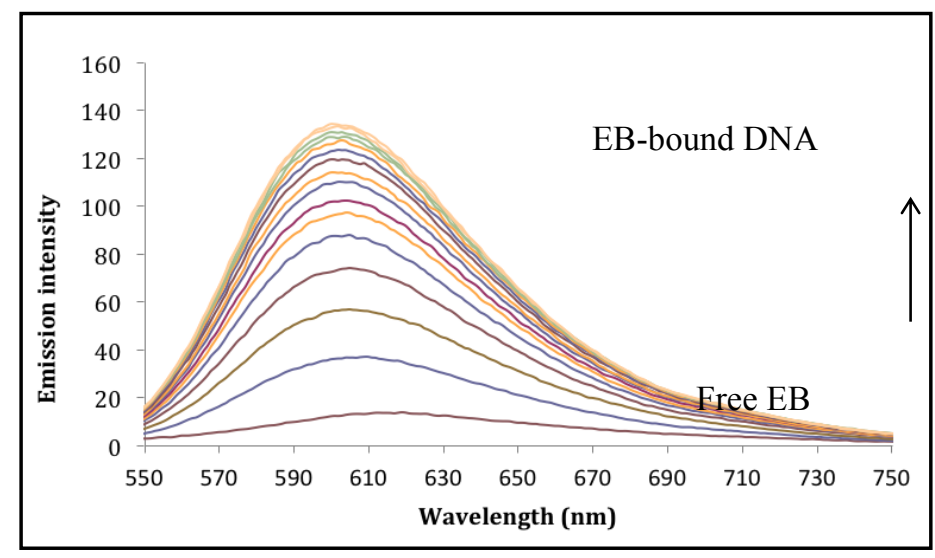

Figure 3. Emission intensity of free EB $(610 \mathrm{~nm})$ and EB-bound DNA $(595 \mathrm{~nm})$

The effect of increasing DNA concentration towards the emission intensity was plotted in Figure 4. The emission intensity rapidly increased with the addition of $0.83 \mu \mathrm{M}$ to $9.17 \mu \mathrm{M}$ DNA. The intercalation of EB into empty space between the base pairs of DNA happens at this point. The emission intensity increased very slowly during the addition of $11.6 \mu \mathrm{M}$ up to $12.5 \mu \mathrm{M}$ DNA, hence suggesting that the base pair on DNA was fully packed with EB at 11.6 $\mu \mathrm{M}$ DNA. The numbers of empty spaces were reduced and the intercalation of EB into DNA base pair was almost saturated.

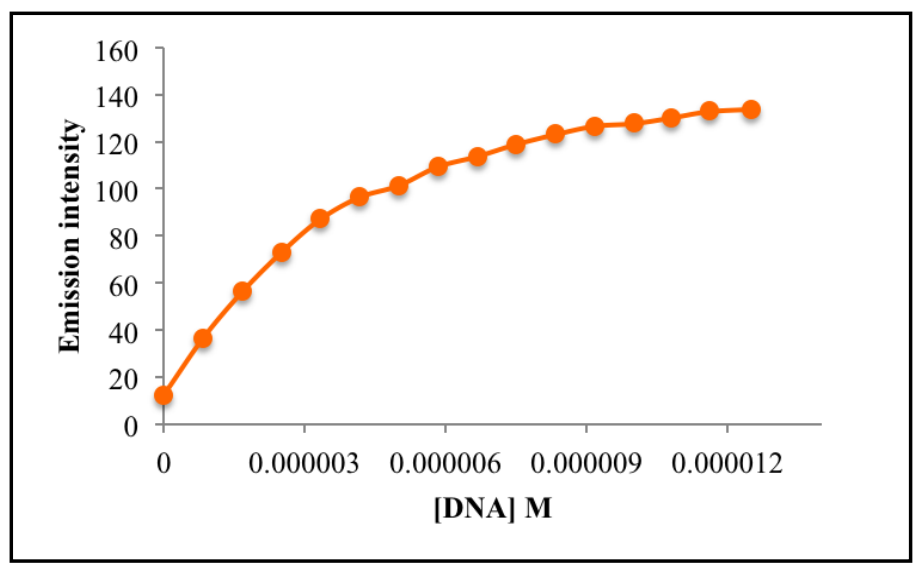

Figure 4. Emission intensity of free $\mathrm{EB}(0.5 \mu \mathrm{M} \mathrm{EB})$ with addition of $0.83 \mu \mathrm{M}$ to $12.5 \mu \mathrm{M}$ DNA

The strength of newly synthesized DESs to quench EB-bound DNA was determined. DES was titrated into saturated EB-bound DNA in increasing DES concentration; 0.025, 0.075, 0.175, 0.300, 0.450, 0.630, 0.830, 1.080, 1.380 and $1.730 \mathrm{M}$. Figure 5 shows that the emission intensities steadily decreased with the addition of four different DESs from $0.025 \mathrm{M}$ to $0.830 \mathrm{M}$. During titration, $\mathrm{TBA}^{+}$from DES, condensed the DNA and formed 


\section{Rizana et al: STUDIES OF INTERACTION BETWEEN TETRABUTYLAMMONIUM BROMIDE BASED DEEP EUTECTIC SOLVENT AND DNA USING FLUORESCENCE QUENCHING METHOD AND CIRCULAR DICHROISM SPECTROSCOPY}

compact molecular structures through electrostatic interaction between $\mathrm{TBA}^{+}$and the negative charge of phosphate on DNA [11]. DES acts as a competing molecule that inhibits the intercalation of EB. This process caused the EB to dissociate from DNA and move into the aqueous solvent, resulting in the decrease of emission intensity. Then, the continuous addition of DES from 1.08 to $1.73 \mathrm{M}$ into EB-bound DNA resulted in no observable change of the emission intensity, indicating the complete removal of EB from DNA base pairs.

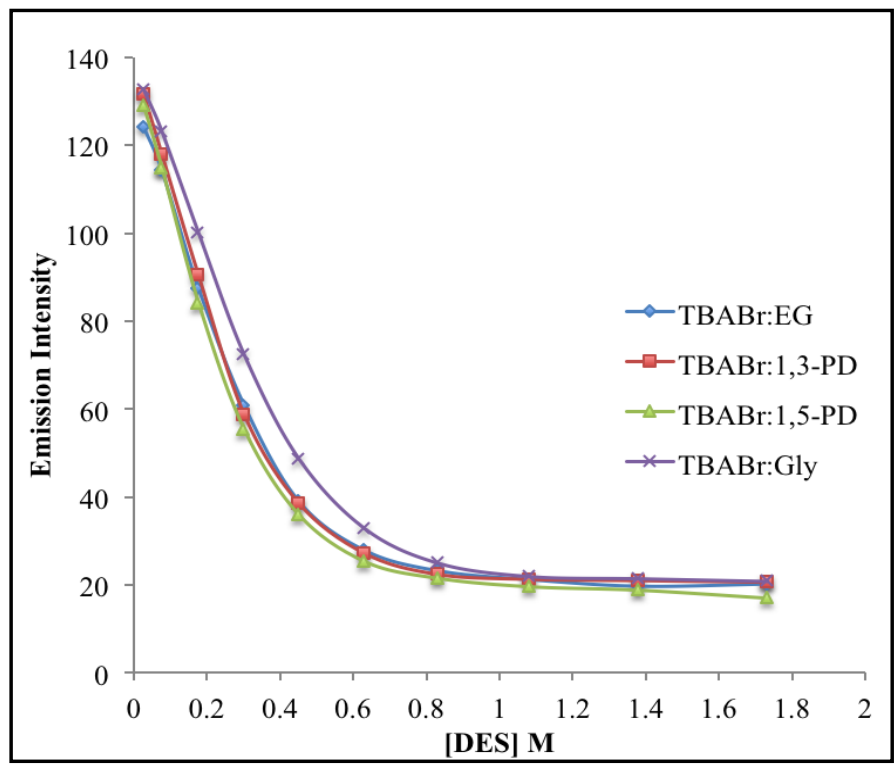

Figure 5. The quenching of EB-bound DNA by addition of different DESs (0.025 to $1.73 \mathrm{M})$

All synthesized DESs are sufficiently strong to quench the intercalation of EB from EB-bound DNA. From this study, the effect of HBD in quenching was observed, in terms of chain length and presence of $\mathrm{OH}$ group. The highest quenching efficiency of DES was shown in order of TBABr:1,5-PD, followed by TBABr:1,3-PD, TBABr:EG to TBABr:Gly. TBABr:1,5-PD has the longest chain length of HBD contributing to the largest hydrophobic effect. The quenching process was caused by the hydrophobic interactions between hydrophobic part of DNA bases and hydrocarbon chain of DES [6]. TBABr:1,5-PD contains five $-\mathrm{CH}_{2}$ groups on 1,5-pentanediol compared to the TBABr:1,3-PD and TBABr:EG which contain of three and two $-\mathrm{CH}_{2}$ groups, respectively. The less number of $-\mathrm{CH}_{2}$ groups reduces the hydrophobic effect, hence decreasing the ability to quench EB. This quenching study suggested that length of HBD has affects the ability of DES to quench EB from EB-bound DNA. This trend is in agreement with the previous reported literature on the binding studies of ILs and DNA, which claimed the quenching efficiency increased with longer alkyl chain lengths of cation in IL[11]. The presence of OH group on DES also plays an important role in the quenching process. Both TBABr:1,3-PD and TBABr:Gly have a similar number of $-\mathrm{CH}_{2}$ groups on HBD. However, TBABr:Gly shows a weaker ability to quench EB from DNA when compared to TBABr:1,3-PD. The presence of three $\mathrm{OH}$ groups on glycerol compared to the two $\mathrm{OH}$ groups on 1,3propanediol reduces the hydrophobic effect on DES, in turn decreasing the ability of the TBABr:Gly to remove EB from EB-bound DNA. These results confirmed the importance of hydrophobic effect of DES in destabilizing the DNA-bound EB complex.

\section{Circular dichroism spectroscopy}

Circular dichroism (CD) spectroscopy is an optical technique that is usually used to analyze the conformational structures of macromolecules, such as DNA. DNA normally exists as double stranded with two polynucleotide chains in opposite directions to form a double helical structure of Watson-Crick base pairs. DNA can exist in many different conformations; right-handed double helical structure of A- and B-conformation of DNA as well as left- 
handed of Z-conformation of DNA. However, the most common and stable DNA structure in solution is the B-conformation of DNA. In order to study the conformation of DNA in DES, the secondary structure on one of the synthesized DES; TBABr:1,5-PD was analyzed by CD. The DES was diluted in aqueous system at fixed concentration of $25 \%$. The effect of DESs concentration to DNA will be studied in the next publication. The study of DNA stability in DES was carried out as DNA is very sensitive towards any changes in its environment such as $\mathrm{pH}$, temperature or concentration [12].

Figure 6 shows the secondary structure of DNA at $25{ }^{\circ} \mathrm{C}$ in $25 \%$ hydrated TBABr:1,5-PD and its control, DNA in aqueous solution at $25{ }^{\circ} \mathrm{C}$. The positive band at $275 \mathrm{~nm}$ and the negative band at $245 \mathrm{~nm}$ are due to the $\pi-\pi$ base stacking and the helicity of DNA, respectively, indicating the characteristics of B-conformation DNA [3]. When DNA was added into $25 \%$ of TBABr:1,5-PD, the magnitude of positive and negative bands increased and decreased respectively. The shift at both the positive and negative bands indicates an electrostatic mode of interaction between the cationic $\mathrm{TBA}^{+}$in DES and anionic phosphate charge of DNA [11]. This observation agreed with the flouorescence results and concluded that DNA in 25\% of TBABr:1,5-PD maintained its B-conformation as both positive and negative bands were observed at the same wavelength. This hypothesis was supported by the UV-vis absorbance graph as shown in Figure 6(b), where the curves of DNA in DESs are similar to the control.
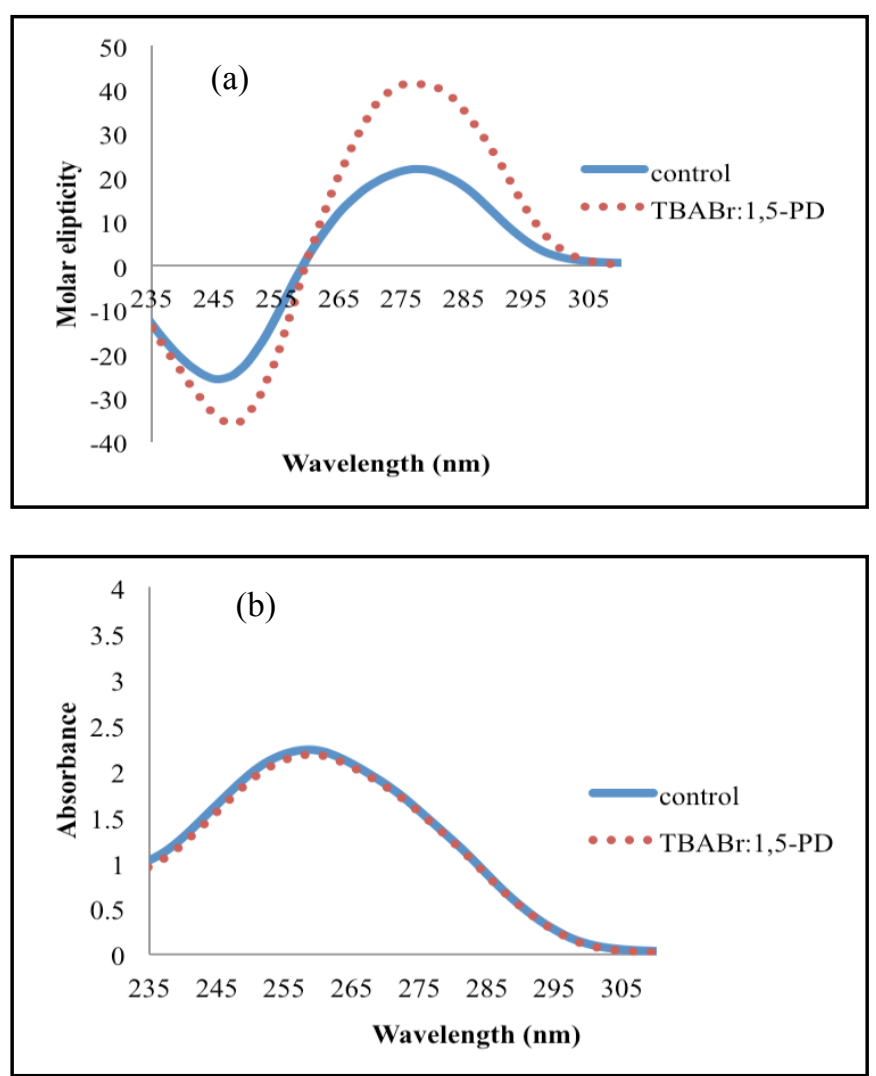

Figure 6. (a) CD spectra (b) absorbance spectra of DNA in 25\% hydrated TBABr:1,5-PD as compare to the control at $25^{\circ} \mathrm{C}$. The control was DNA in aqueous solution.

\section{Conclusion}

All synthesized DESs; TBABr:EG, TBABr:1,3-PD, TBABr:1,5-PD and TBABr:Gly were strong enough to displace the intercalation of EB from DNA. The strongest DES that quenched EB from DNA was the one that was most 


\section{Rizana et al: STUDIES OF INTERACTION BETWEEN TETRABUTYLAMMONIUM BROMIDE BASED DEEP EUTECTIC SOLVENT AND DNA USING FLUORESCENCE QUENCHING METHOD AND CIRCULAR DICHROISM SPECTROSCOPY}

hydrophobic with the longest HBD and the least $\mathrm{OH}$ group, TBABr:1,5-PD. Hydrophobic interactions contributes to the ability of DESs to quench DNA from EB. The affinity of DESs toward DNA was due to the electrostatic interactions between the TBA ${ }^{+}$cation of DES and phosphate backbone of DNA. These hypotheses were confirmed by fluorescence and CD spectroscopy. DNA was able to maintain its B-conformation in TBABr:1,5-PD at $25{ }^{\circ} \mathrm{C}$ with $25 \%$ concentration.

\section{Acknowledgement}

This work was supported by Research University Grant Scheme (RUGS), (Grant No. 9341900), Universiti Putra Malaysia, Malaysia. Rizana Yusof thanks Universiti Teknologi MARA (UiTM), Malaysia and the Ministry of Higher Education Malaysia for the financial support throughout her Ph.D.

\section{References}

1. Cheng, Q., Benson, D. R., Rivera, M. and Kuczera, K. (2006). Influence of point mutations on the flexibility of cytochrome b5: molecular dynamics simulations of holoproteins. Biopolymers, 83, $297-312$.

2. Marrazza, G., Chianella, I. and Mascini, M. (1999). Disposable DNA electrochemical biosensors for environmental monitoring. Analytica Chimica Acta, 387: 297 - 307.

3. Vijayaraghavan, R., Izgorodin, A., Ganesh, V., Surianarayanan, M. and MacFarlane, D. R. (2010). Long-term structural and chemical stability of DNA in hydrated ionic liquids. Angewandte Chemie International Edition, 122: $1675-1677$.

4. Mamajanov, I., Engelhart, A. E., Bean, H. D. and Hud, N. V. (2010). DNA and RNA in anhydrous media: duplex, triplex, and G-quadruplex secondary structures in a deep eutectic solvent. Angewandte Chemie International Edition, 49: 6310 - 6314.

5. Sharma, M., Mondal, D., Singh, N., Trivedi, N., Bhatt, J. and Prasad, K. (2015). High concentration DNA solubility in bio-ionic liquids with long-lasting chemical and structural stability at room temperature. RSC Advances 5: $40546-40551$.

6. Ding, Y., Zhang, L., Xie, J. and Guo, R. (2010). Binding characteristics and molecular mechanism of interaction between ionic liquid and DNA. Journal of Physical Chemistry B, 114: 2033 - 2043.

7. Yusof, R., Abdulmalek, E., Sirat, K., and Rahman, M. B. A. (2014). Tetrabutylammonium bromide (TBABr)based deep eutectic solvents (DESs) and their physical properties. Molecules, 19: 8011 -8026.

8. Sirajuddin, M., Ali, S. and Badshah, A. (2013). Biology drug-DNA interactions and their study by UV-visible, fluorescence spectroscopies and cyclic voltametry. Journal of Photochemistry and Photobiology B: Biology, 124: $1-19$.

9. Street, N. S. (1995). Criteria for the mode of binding of DNA binding agents. Bioorganic and Medicinal Chemistry, 3: $723-728$.

10. Beckford, S. R. J. (2012). Biophysical characterization of the binding of homologous anthraquinone amides to DNA. Doctoral Dissertation, Georgia State University, United State.

11. Manojkumar, K., Prabhu Charan, K. T., Sivaramakrishna, A., Jha, P. C., Khedkar, V. M., Siva, R., Jayaraman, G. and Vijayakrishna, K. (2015). Biophysical characterization and molecular docking studies of imidazolium based polyelectrolytes-DNA complexes: Role of hydrophobicity. Biomacromolecules, 16: 894 - 903.

12. Corrêa, D. H. A. and Ramos, C. H. I. (2009). The use of circular dichroism spectroscopy to study protein folding, form and function. African Journal of Biochemistry Research, 3: $164-173$. 